Edison General Electric Co. to form the General Electric Co. (America), the largest manufacturing company of electrical equipment in the world. Thomson retained his post as director of the large laboratory at Lynn, which was renamed after him, the Thomson Laboratory.

Thomson made more than seven hundred inventions, some of which have led to great developments and many theoretical discoveries. $\mathrm{He}$ discovered that the resistance of the electric arc varies inversely with the current. He was the first to utilize a magnetic field to move the electric arc, a method which is used in magnetic blow-out switches and electric safety valves. A notable discovery was that a copper ring placed in front of an A.C. magnet was strongly repelled, a fact which he applied to the development of repulsion motors which are much used in industry. $\mathrm{He}$ was the pioneer of high-frequency apparatus, making the first dynamo of this type in 1890. In 1886, he invented the art of electric welding by the resistance method. The art of welding has developed very rapidly since this date. Ships, buildings, bridges, etc., are now being welded instead of being riveted and bolted. It has also proved of great value when designing aeroplanes and large motor vehicles. His inventions show great novelty of design. The Thomson-Houston dynamo for arc lighting had a spherical armature, cup-shaped field magnets and a three-part commutator. He made most useful contributions to the field of radiology and was the first to make stereoscopic X-ray pictures.

In 1884, Dr. Thomson married Miss Mary Peck of New Britain, Conn., by whom he had four sons. Mrs. Thomson died in 1916, and seven years afterwards he married Miss Clarissa Hovey of Boston and lived at Swampscott near Lynn, where he continued his inventive work.

Elihu Thomson received many honours for his electrical and scientific work from countries all over the world. He made many friends when he was president of the International Electrical Congress at St. Louis in 1904 and of the International Electrotechnical Commission which met in Turin in 1911. The writer remembers how feelingly Elihu Thomson spoke of Prof. Silvanus Thompson when a portrait of the latter was presented in 1923 to the Institution of Electrical Engineers. He said that he felt that the late Prof. Silvanus Thompson was in many respects nearer to himself than any other man. $\mathrm{He}$ was successful not only in electrical work, but as an optician, a musician and an artist he had also attained distinction. He felt that in his own way he was humbly following in Thompson's footsteps.

When he was presented with the Kelvin Medal in 1924 by the leading engineering institutions in Great Britain, Elihu Thomson said that Kelvin was his ideal, as an influence and example that was not to be estimated by ordinary standards. Kelvin was lovable as a man, and unequalled as a scientific expert. Thomson regarded him as the earliest and greatest electrical engineer. In 1924, the University of Manchester, his native city, conferred on Thomson the honorary degree of doctor of science. At the festivities which took place at the World Power
Conference in 1924, he and Mrs. Thomson took a leading part and were esteemed by everyone. Since then, many of us have received at Christmas time from them beautiful photographs of their garden takeh in natural colours by a new method invented by Thomson. He will be missed by his many friends all over the world.

A. R.

\section{Baron de Stael Holstein}

WE regret to record the death of Baron de Stael Holstein, well known as an Oriental scholar, which is reported to kave taken place recently in Peking at the age of fifty-seven years.

Baron de Stael Holstein was formerly one of the largest landowners in the Russian Baltic States; but on being dispossessed by the Revolution, he took up his residence in Peking, where he devoted himself to the study of Sanskrit and Buddhism, of which he had long been an ardent follower, adding to them Tibetan and Chinese. In so doing, he was anxious to bring about a better understanding of the Buddhist canon among the Chinese themselves, and for the furtherance of this object founded, with the cooperation of Harvard University, the Sino-Indian Institute, in which Tibetan lamas were engaged for instructional purposes, but at the same time initiated into Western methods of critical scholarship. With the assistance of American benefactions, he brought together a remarkable collection illustrating Buddhist iconography. His eminence as an Oriental scholar was recognized by the University with which his Institute was connected when he was called to Harvard for a time to occupy the chair of Sanskrit. His literary output was considerable, his work of most enduring value being the publication of a number of Buddhist texts.

\section{Dr. F. P. F. Ransom}

Dr. F. P. F. Ransom, who died on February 23 at the age of eighty-seven years, studied pharmacology as a young man in Halle and Marburg with von Behring and H. H. Meyer. They studied immunity, and the pharmacology of tetanus toxin and diphtheria toxin. They obtained evidence that these toxins passed.from the periphery to the central nervous system in the trunks of nerves. Ransom also showed that the toxic effects of saponins were largely due to their affinity for cholesterol, and made an active cell-free cholera toxin.

At the age of sixty years, he was elected to a Beit fellowship, and, with Dixon in Cambridge, demonstrated the action of sympathetic and parasympathetic nerves on the bronchi. From 1912 until 1924 he held first a readership and then a chair at the London School of Medicine for Women, and published papers on the effect of eaffeine on seeds, on alcohol, chloroform, pilocarpine and other subjects. His wide knowledge of pharmacology was always at the disposal of his colleagues, and he will be remembered as a kind, modest and courteous friend. He spent his last years in retirement in Somerset, and kept up his interest in pharmacologv in spite of failing eyesight. 